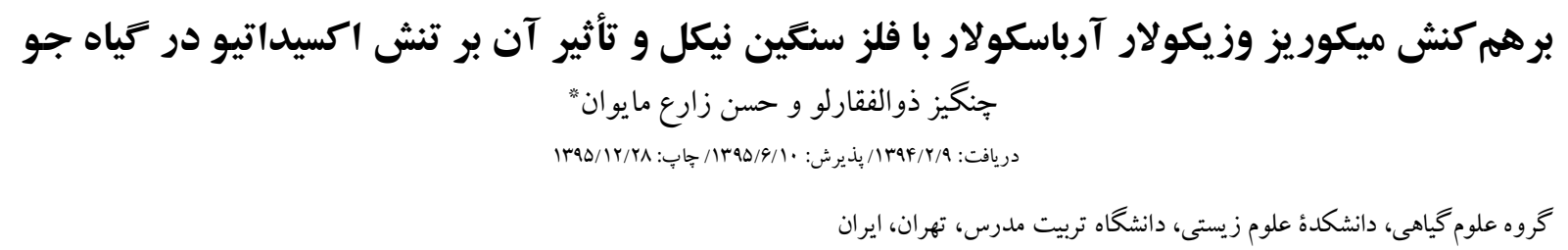

zaremaih@modares.ac.ir :

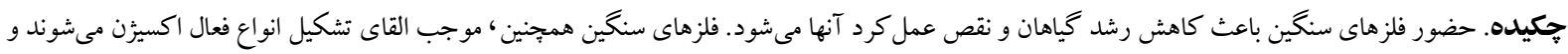

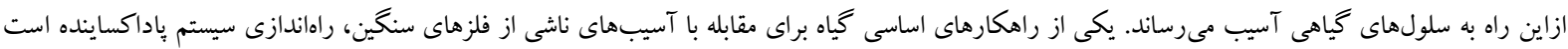

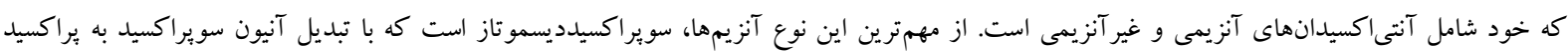

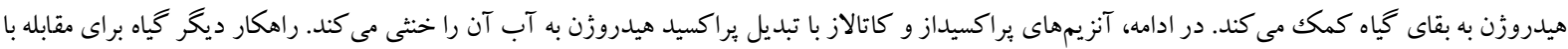

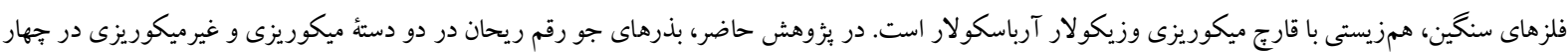

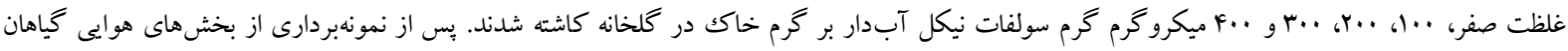

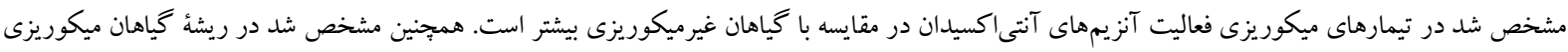

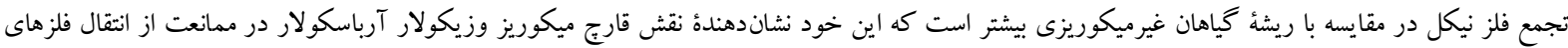

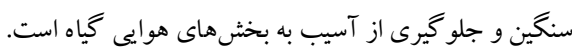

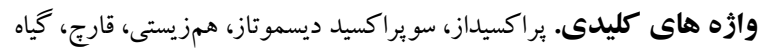

\title{
Interaction of vesicular arbuscular mycorrhiza with nickel heavy metal and its effect on the oxidative stress in barley
}

Changiz Zolfagharlou \& Hasan Zare-Maivan*

Received 29.04.2015/ Accepted 31.08.2016/Published 18.03.2017

School of Biological Sciences, Tarbiat Modares University, Tehran, Iran

*Correspondent author: zaremaih@modares.ac.ir

\begin{abstract}
Heavy metals reduce the plant growth and adversely affect plant performance potential. Heavy metals also induce the formation of reactive oxygen species leading to cell damage. Plants deal with heavy metal stress by activating enzymatic and non-enzymatic antioxidant systems such as Superoxide Dismutase which converts superoxide anion to hydrogen peroxide. Then Peroxidase and Catalase convert hydrogen peroxide to water. Another method employed by pl-ants to deal with heavy metals is mycorrhizal symbiosis. In this study, mycorrhizal and nonmycorrhizal barley seedlings (Hordeum vulgar), var. Rayhan, grown in a greenhouse were treated with four concentrations of nickel $(0,100,200$ and $400 \mu \mathrm{g} / \mathrm{g})$. Results showed greater antioxidant activity in mycorrhizal plants compared with non-mycorrhizal plants. Also, it was determined that the accumulation of nickel in roots of mycorrhizal plants was greater compared with non-mycorrhizal plants.
\end{abstract}

Keywords. peroxidase, superoxide dismutase, symbiosis, fungi, plant

محيط مىشود (Salt, 2000; Alloway, 1995). غلظت نيكل در خاككهاى آلوده ممكن است تا

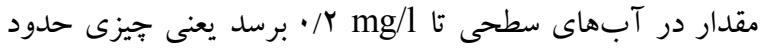

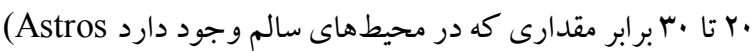
Bjorklund, 1996; Zwolsman, 2007)

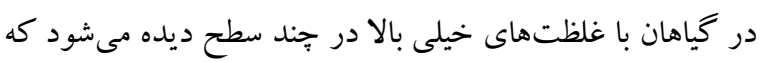

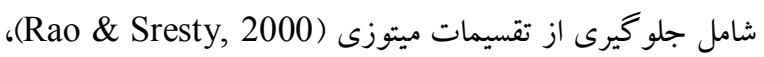
كاهش رشد ميزان آب نسبى و فتوسنتز گياه، جلو گيرى از فعاليت

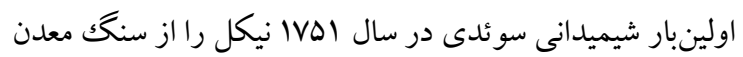

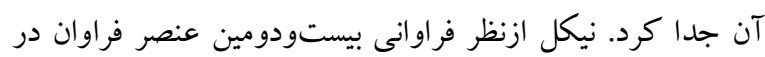

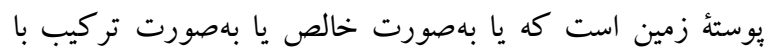
آهن در سنگكهاى آذرين يافت مىشود (Sunderman, 1991).

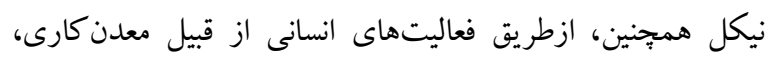

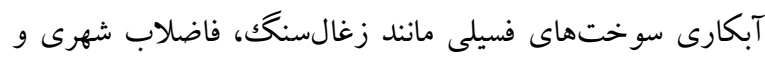
صنعتى، كودهاى كشاورزى و شيميايى و دود وسائل نقليه وارد 
كياهان جو تحت تنش فلز نيكل در حضور ميكوريز وزيكولار

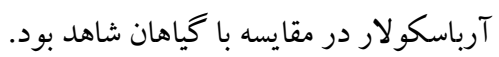

\section{مواد و روشها}

بذرهاى كياه جو (Hordeum vulgar L.) از بخش غلات شهرك نهال و بذر محمدشهر كرج تهيه شد. بذرها ابتدا با مايع بـان دستشويى و آب مقطر شسته شد. سيس، بهمدت ^ دقيقه در آب

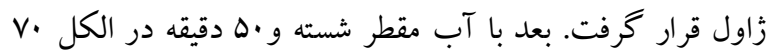

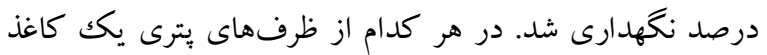
واتمن قرار داده شد و با جند قطره آب مقطر استريل و مرطوب تهري

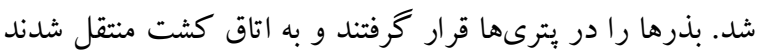

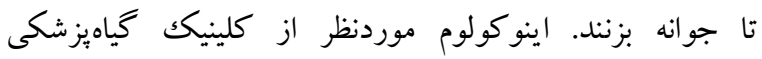

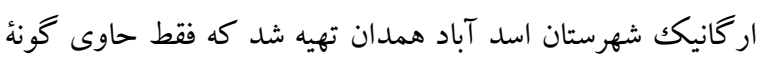
ميكور يزايى Glomus mossae به همر اه ريشٔ هيف و خاكك بود.

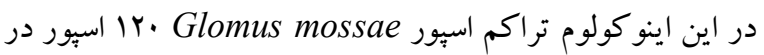

$$
\text { هر كرم نمونه خاكك بود. }
$$

\section{انتقال بذرها به كلدان در كلخانه}

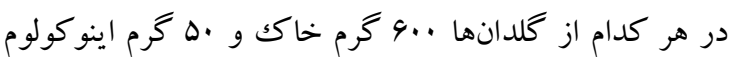

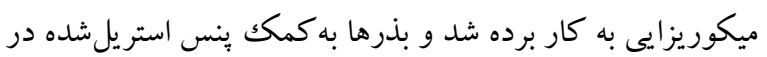

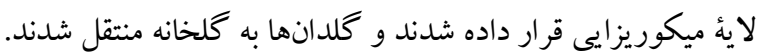

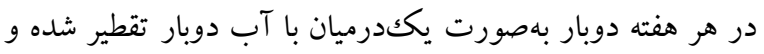

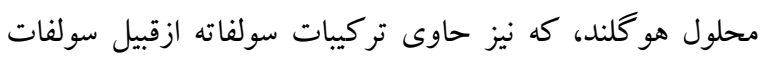

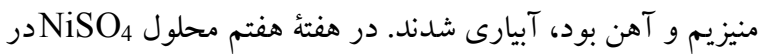

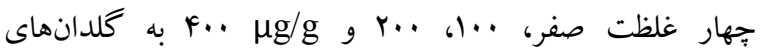
ميكوريزى و غيرميكوريزى اضافه شد. دو هفته بعد از اعمال فلز

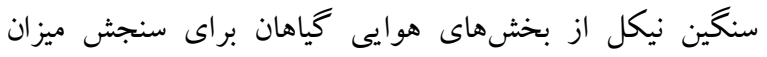

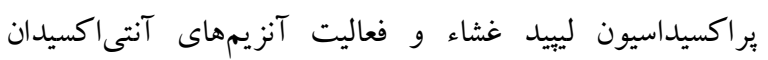

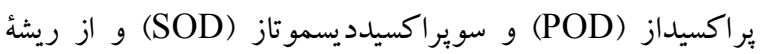

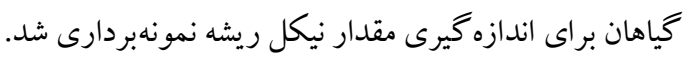

$$
\text { فعاليت آنزيم يراكسيداز }
$$

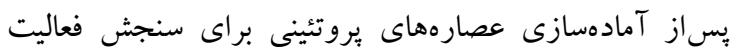

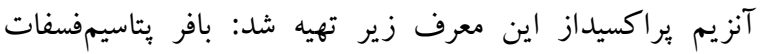

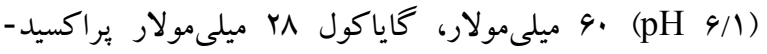

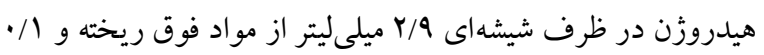
ميلى ليتر عصارة آنزيمى به آن اضافه شد و بلافاصله جذب محلول
آنزيمى، متابوليسم نيتروزن (Gajewska et al., 2009)، مداخله در جذب فلزهاى ضرورى ديخر و تحريك تنش اكسيداتيو نتوني (Chen et al., 2009) سنخين مانند نيكل، كادميوم و روى ازطريق مسيرهاى اكسيداتيو و

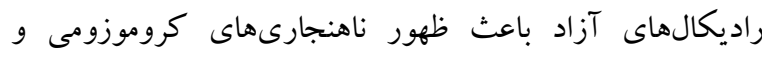
كاهش رشد گياه مى شود

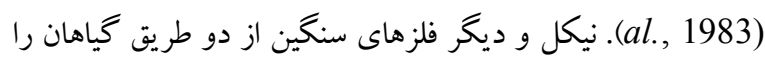
تحت تأثير قرار مىدهند: با تغيير ويز گیىهاى كينيتيكى و ميزان

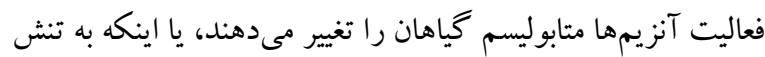

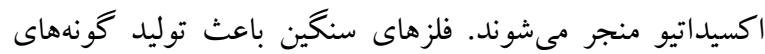

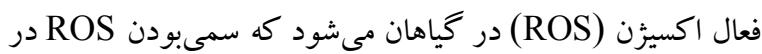

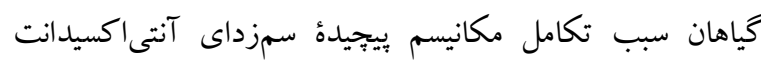

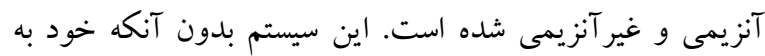

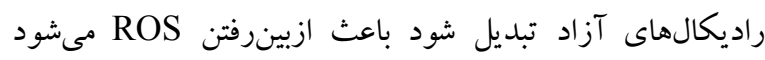

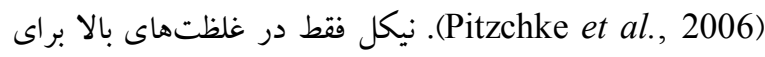

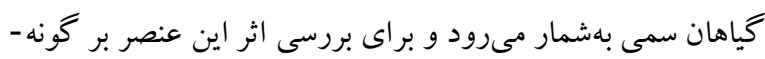

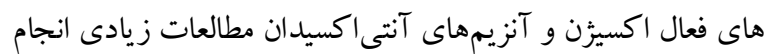

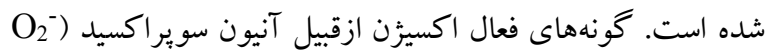

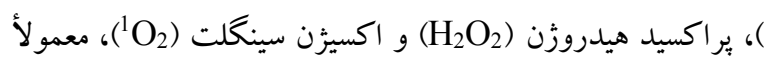

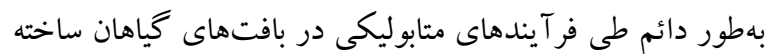

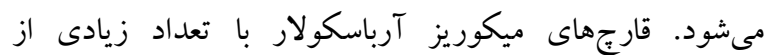

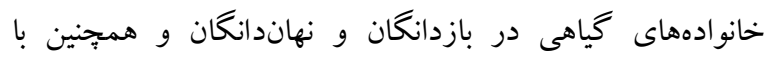

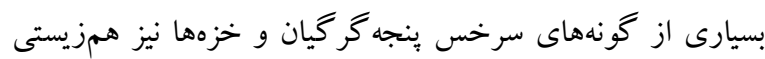
دارند (Conway \& Bagyaraj, 1984). قارجهاى ميكوريز

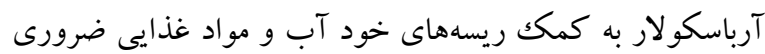

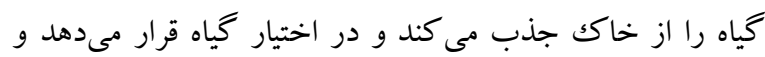

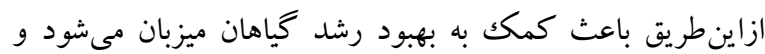
درعوض كربوهيدراتهاى مورد نياز را از كياه دريافت مى كند مئد

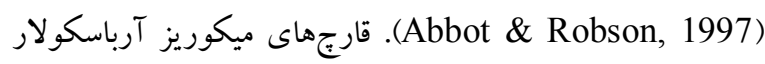

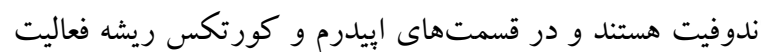
مى كنند. هدف اين تحقيق بیىبردن به تغيير فعاليت آنزيمهاى

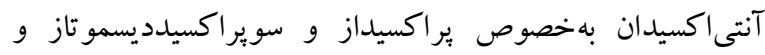
ميز ان مالون دى آلدهيد به منزلة شاخصى از براكسيداسيون غشا در 
براساس روش Heath و Packer (1968) اندازهگيرى شد.

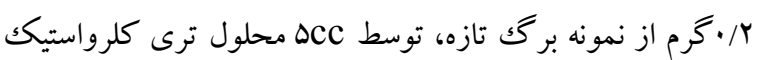

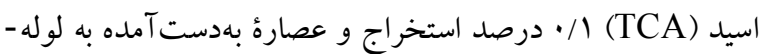
هاى سانتريفوز منتقل شد و در دماى محيط، دور ..... بهمدت

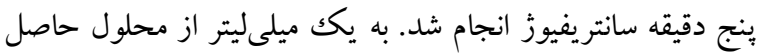

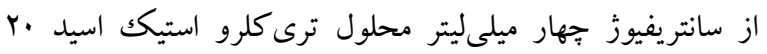
درصد حاوى ه/· درصد تيوبابيتوريككاسيد (TBA) اضافه شد.

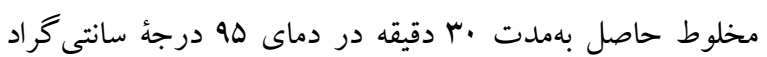

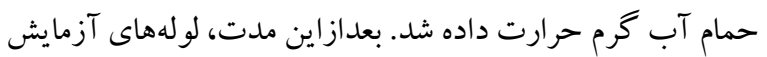

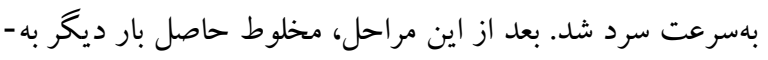

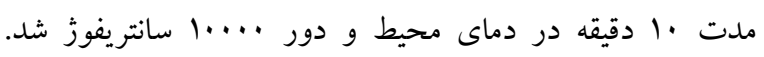
جذب محلول رويى حاصل از سانتريفيوز بهوسيلة دستگاه اسبكتروفتومتر و طول موج بrه نانومتر خو انده شد. مادهُ موردنظر در اين طول موج كميلكس قرمزرنگك (MDA-TBA) است.

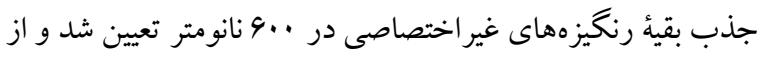

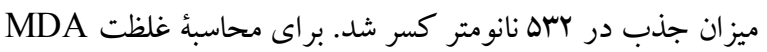

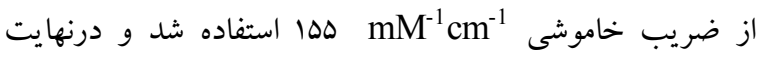

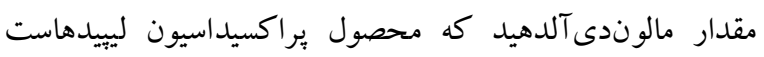
بر اساس ميكرومول وزن تر محاسبه شد.

\section{سنجش ميزان فلز نيكل در ريشه}

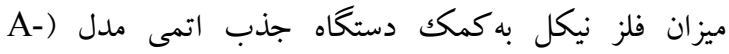

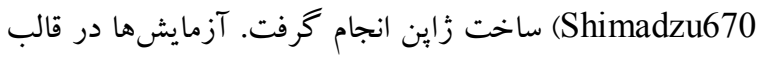
طرح كاملأ تصادفى و دادهها براساس آزمون دانكن با سهبار تكرار

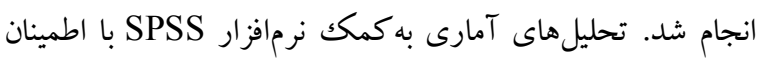

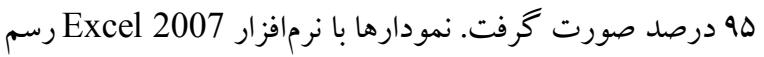

\section{نتايج}

\section{فعاليت آنزيم يراكسيداز در بركىها}

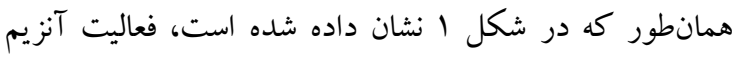

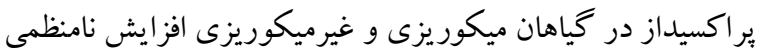

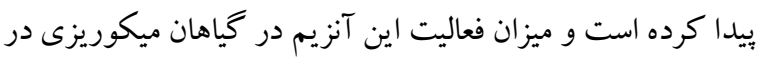
مقايسه با كياهان غير ميكوريزى در سطح ه دروصد معنىدار نيست.

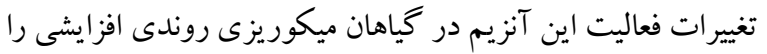

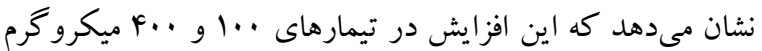

در طول موج ·FV نانومتر با استفاده از دستكاه اسبكتروفتومتر

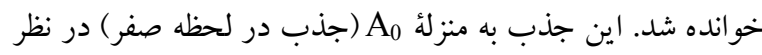

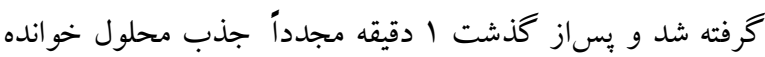

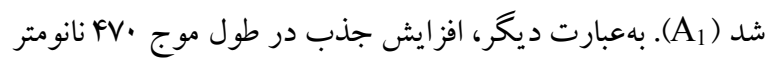

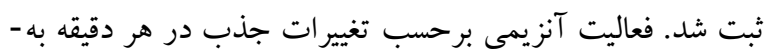
ازاى هر ميلى گرم يروتئين محاسبه شد. فعاليت آنزيم سوير اكسيدديسموتاز

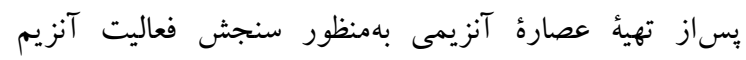

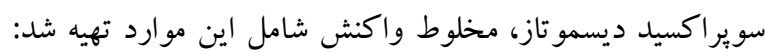

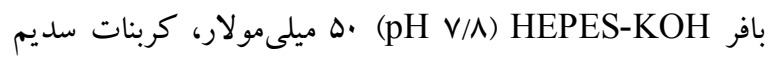

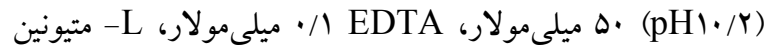
T I Tيلىمولار، نيتروبلوتترازوليوم VD ميلىمولار، ريبوفلاوين

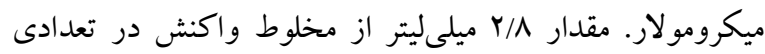

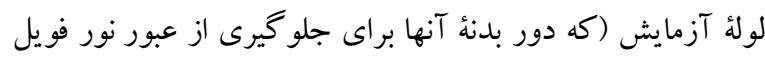

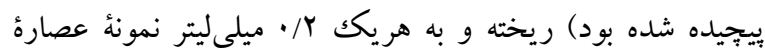

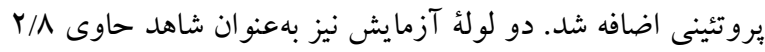

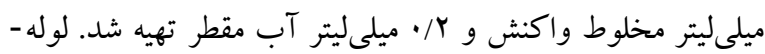

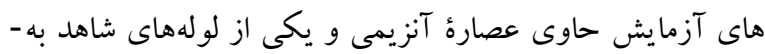

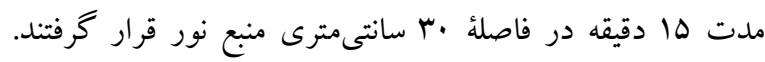

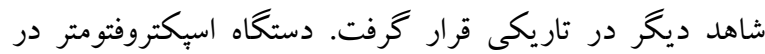

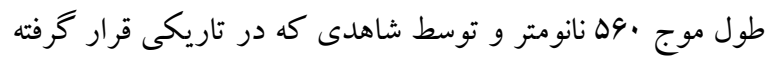

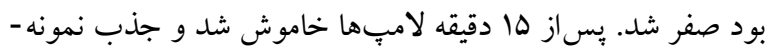

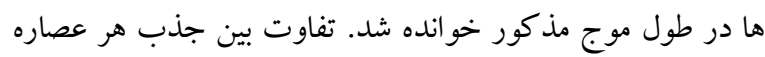
در مدت زمان روشنايى 10 دقيقه و جذب عصول مصارهُ بدون آنزيم (شاهد) در همان زمان روشنايى، در واقع، نشاندهندة فعاليت آنزيم

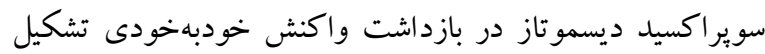
فورمازان است. بنابراين، درصد كاهش جذب براى هر نمونه

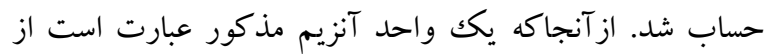

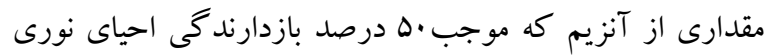

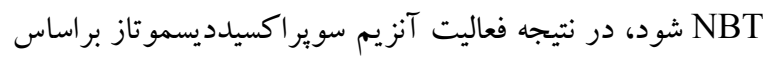

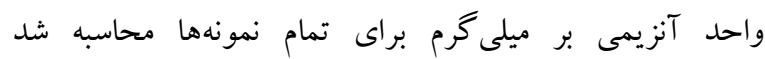
(Gionnopolitis \& Reis, 1997)

سنجش ميزان بر اكسيداسيون ليييدها براى سنجش ميز ان براكسيداسيون ليبيدهاى غشا، غلظت مالون

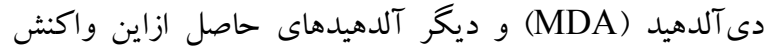


قارج VAM تنها گونهُ قارجى است كه مىتواند بين ريشه، خاكك و موقعيت تنشزاى فلزهاى سنگين از قبيل نيكل ارتباط

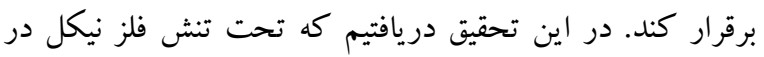

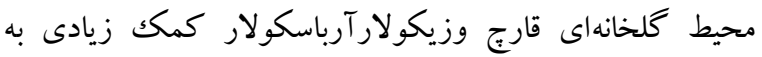
جذب فلز نيكل و فعالشدن آنزيمهاى آنتىاكسيدان مى كند. دادههاى اين تحقيق مبين آن است كه كلونيزاسيون ريشه تحت

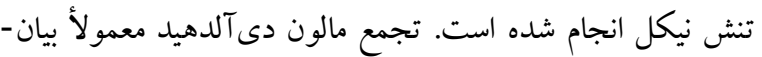

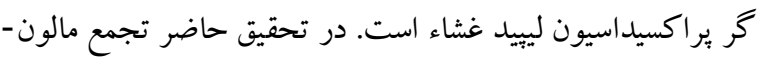

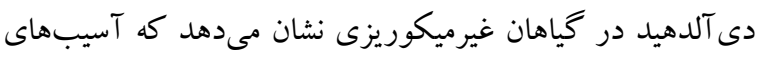

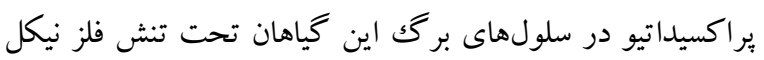

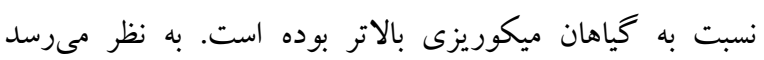

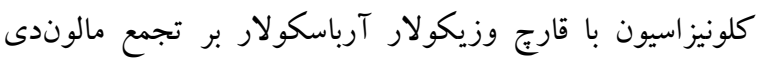
آلدهيد تأثير منفى دارد. ازطرف ديخر آنزيم سوير اكسيد ديسمو تاز يكك آنزيم كليدى در تخريب راديكالهاى سويراكسيد و توليد ير اكسيد هيدروزن است. در تحقيق حاضر ميزان فعاليت اين آنزيم در گياهان ميكوريزى

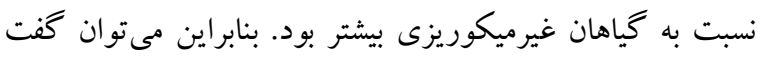

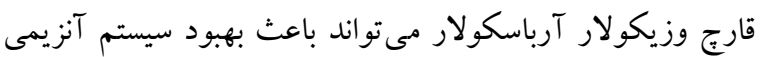
آنتى اكسيدانت در گياهان تحت تنش فلزهاى سنگين شود. فعاليت

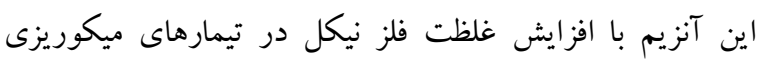

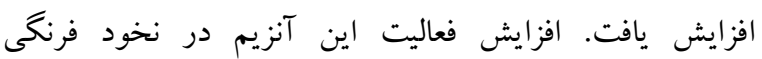

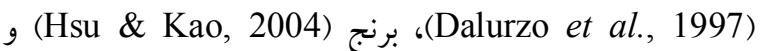

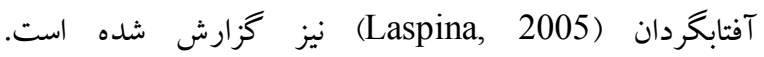

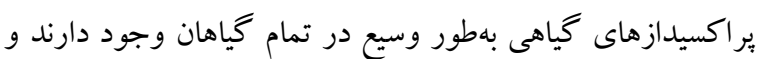
يكى از نقشهاى آنها مشاركت در سيستم دفاعى سلول و وسم سمر -

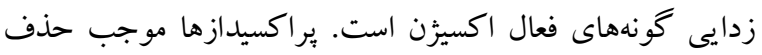
يراكسيد هيدروزن توليد شده توسط عوامل تنشزا مى شوند. اين

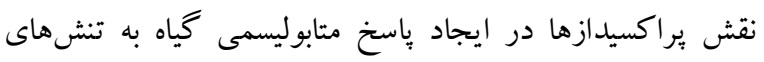
مختلف و حفظ سلول در مقابل غلظتهاى زيانآور ڤيراكسيد هيدروزن حائز اهميت فراوان است (Hiraga, 2001). در اين تحقيق مشاهده شد فعاليت آنزيم ير اكسيداز همواره در كياهان ميكوريزى نسبت به گياهان غيرميكوريزى بيشتر است به طورى كه اين افزايش در تيمار .. نيكل معنىدار است. همجنين مشاهده شد با افزايش غلظت فلز نيكل از غلظت . .. نيكل به بعد،
نيكل، در سطح ه درصد معنىدار است. در گياهان غيرميكور يزى، ه.

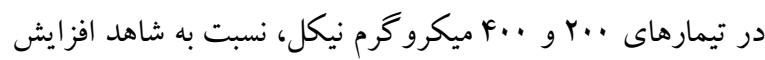

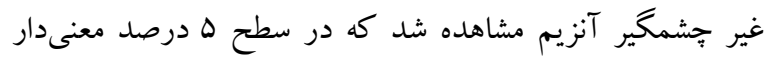
فعاليت آنزيم سويراكسيدديسموتاز در بركهها

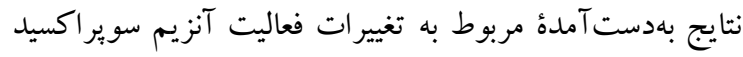

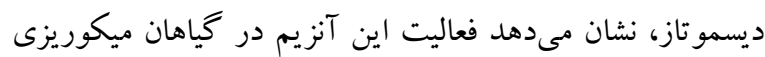

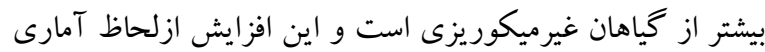

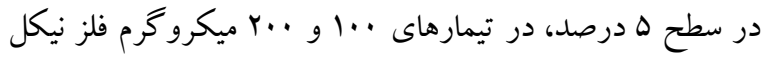

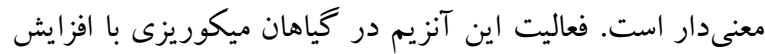

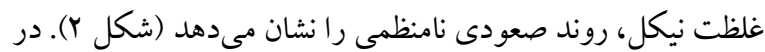

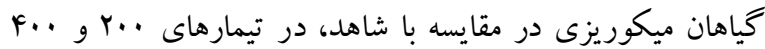
ميكرو گرم نيكل افزايش فعاليت آنزيم ديده مىشود و اين افزايش در سطح ه درصد معنىدار است. درگياهان غيرميكوريزى در

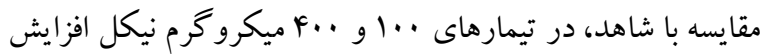
فعاليت آنزيم ديده مىشود و اين افزايش در سطح ه درصد معنى -

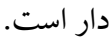
مقدار مالون دى آلدهيد MDA در بر كَها نتايج حاصل از بررسى ميزان مالون دى آلدهيد آدهيد در كياهان

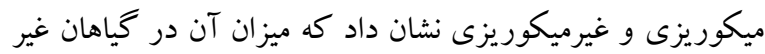

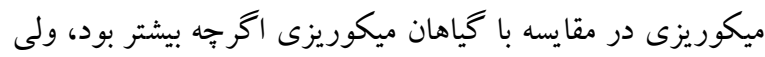

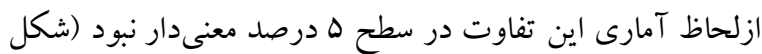
(r)

غلظت نيكل در ريشه همانطور كه در شكل \& نشان داده شده است غلظت نيكل در

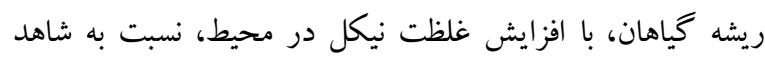
فزايش معنى دارى در سطح ه درصد بيدا مى كند و بيشترين غلظت دئل

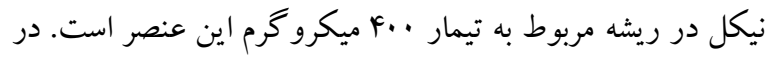

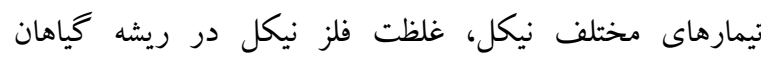
ميكوريزى نسبت به گياهان غيرميكوريزى بيشتر است و و اين افزايش در تيمار ... ميكرو گرم نيكل، معنى دار است. 


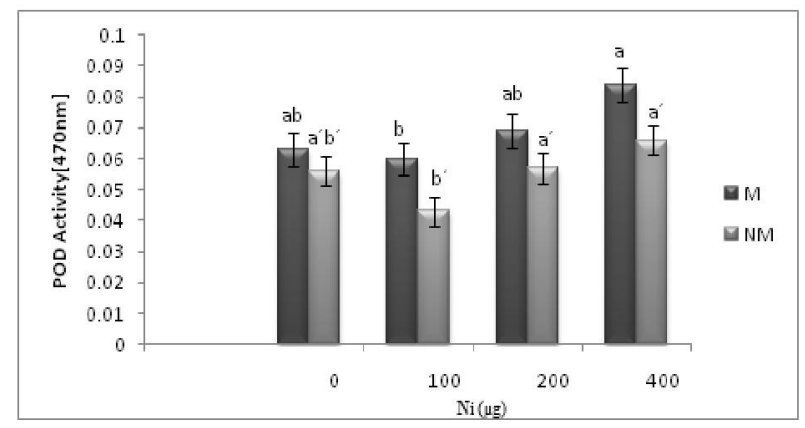

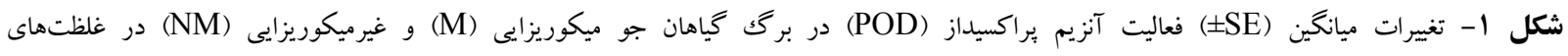

مختلف NiSO

Fig. 1. The activity of POD in the leaves of mycorrhizal (M) and non-mycorrhizal (NM) barley plants treated with different concentrations of $\mathrm{NiSO}_{4} \cdot 6 \mathrm{H}_{2} \mathrm{O}$. Bars with different letters are significantly different at $p \leq 0.05$.

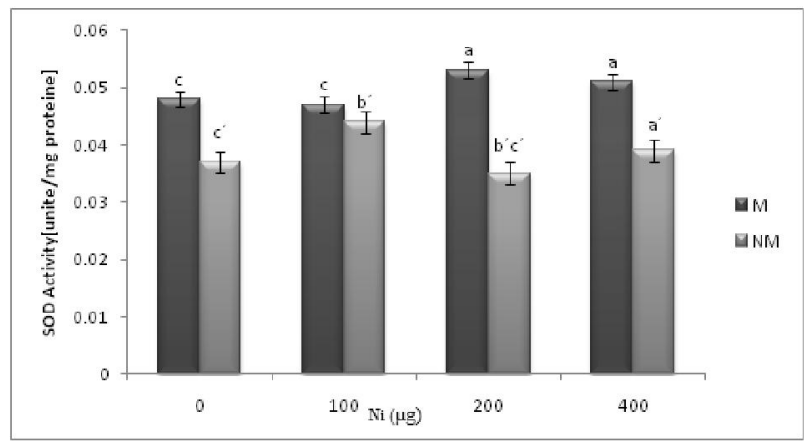

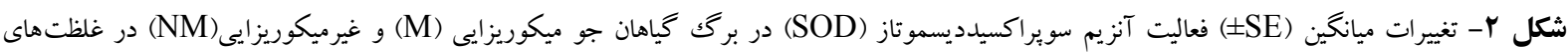
مختلف NiSO4.6 H2O حروف متفاوت نشاندهندة اختلاف معنى دار در سطح ه درصد است و ميلههاى عمودى انحر اف معيار را نشان مى دهد.

Fig. 2. The activity of SOD in the leaves of mycorrhizal (M) and non-mycorrhizal (NM) barley plants treated with different concentrations of $\mathrm{NiSO}_{4} \cdot 6 \mathrm{H}_{2} \mathrm{O}$. Bars with different letters are significantly different at $p \leq 0.05$.

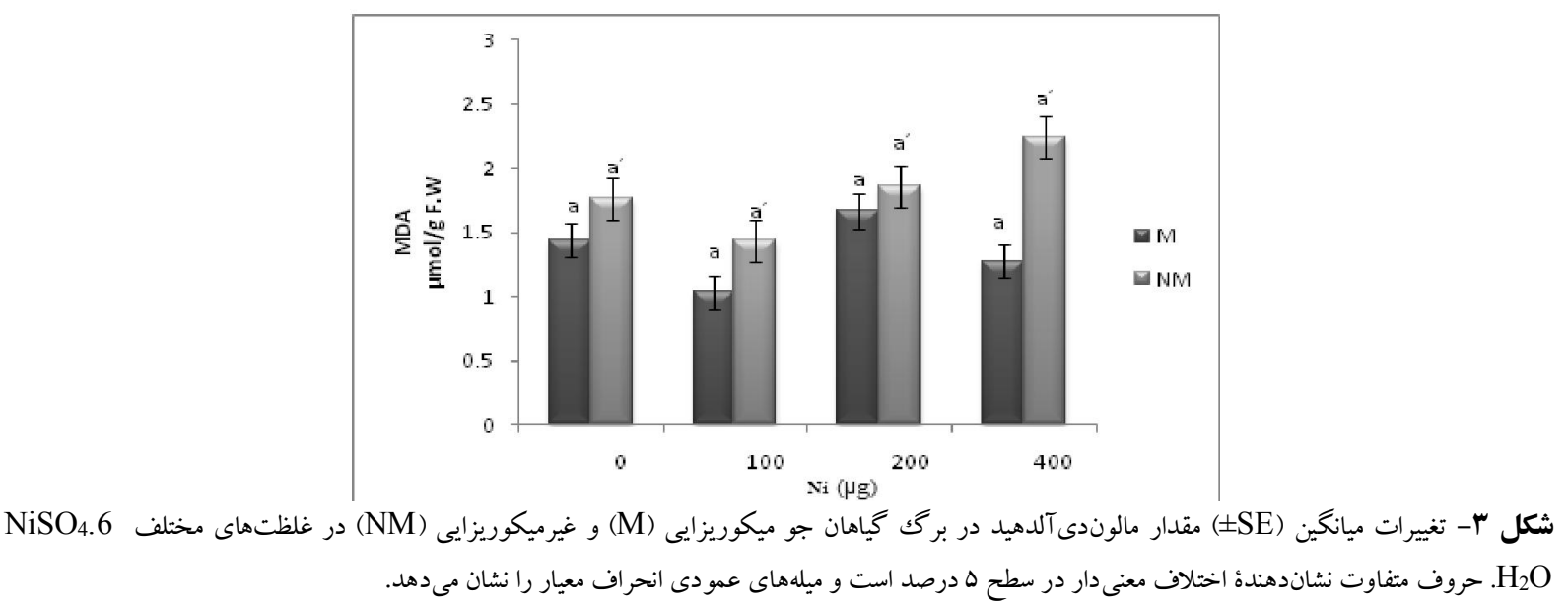

Fig. 3. Amount of MDA in the leaves of mycorrhizal (M) and non-mycorrhizal (NM) barley plants, treated with different concentrations of $\mathrm{NiSO}_{4} \cdot 6 \mathrm{H}_{2} \mathrm{O}$. Bars with different letters are significantly different at $p \leq 0.05$. 


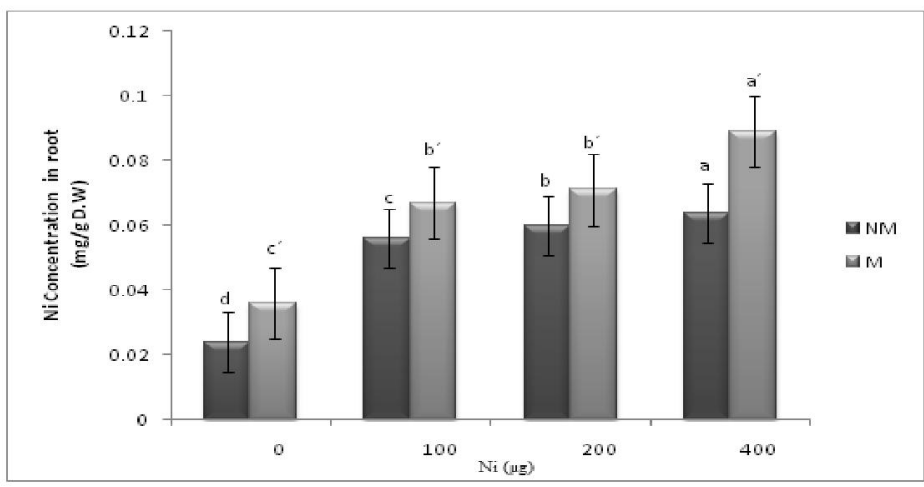

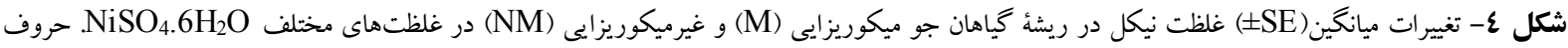

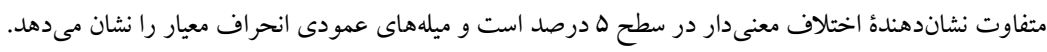
Fig. 4. Ni content in the roots of mycorrhizal (M) and non-mycorrhizal (NM) barley plants treated with different concentrations of $\mathrm{NiSO}_{4} \cdot 6 \mathrm{H}_{2} \mathrm{O}$. Means with different letters are significantly different at $p \leq 0.05$.

كزارش دادند غلظتهاى مختلف سولفات تأثيرى بر كميت و

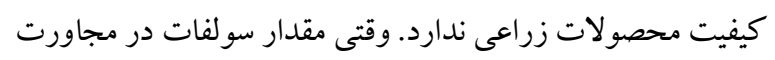

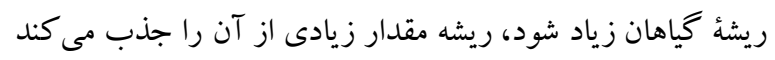

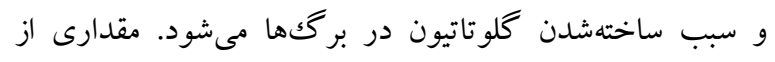

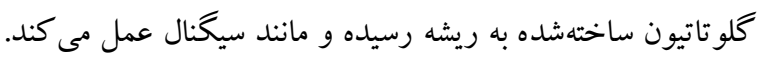

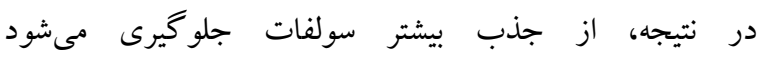

.(Herschbach \& Ronnenberg, 1994)

نتيجه كيرى

با توجه به دادههاى حاصل از سنجش آنزيمهاى آنتى اكسيدان

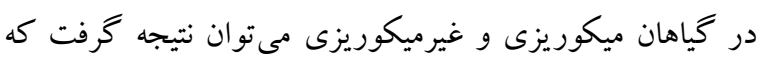
فعاليت آنزيمهاى آنتىاكسيدان بهوسيلة ميكوريز وزيكوديكورئلار آرباسكولار در كياه جو تحريكك شد. درعين حال افزايش فعاليت

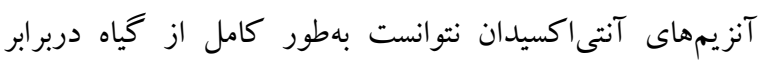

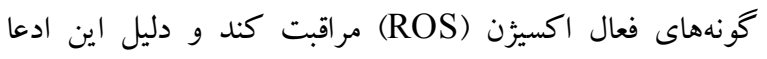
براكسيداسيون غشاء حتى در حضور اين آنزيمهاست. در حضور ميكوريز وزيكولار آرباسكولار فلز نيكل در ريشه تجمع بيشترى بيدا كرد.

سياسگزارى بدينوسيله از معاونت يُزوهشى دانشكاه تربيت مدرس و موسسه تحقيقات تهيه بذر و نهال تشكر مى گردد.
فعاليت آنزيم يراكسيداز افزايش منظمى بيدا مى كند. گزارشهاى

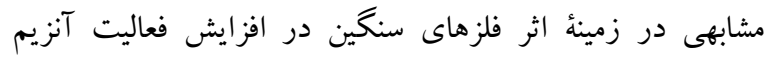

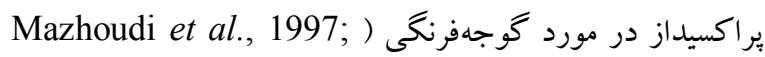

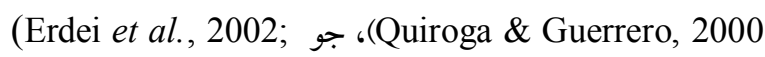
Laspina \& Groppa ) (Gue et al., 2007) 2005) و نخود فرنكى (Chaoui \& Ferjani, 2005) ارائه شده است. در تحقيق حاضر غلظت نيكل ريشهاى گياه جو در گياهان ميكوريزى و غيرميكوريزى افزايش ويدا كرد، البته در خياهان

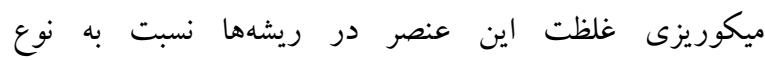
Simon \& ) غيرميكوريزى بيشتر بود كه اين نتايج با تحقيقات

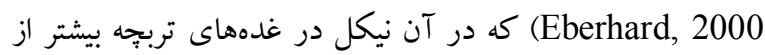

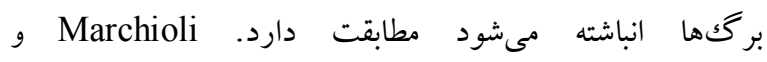
همكاران (2004) نيز گز ارش مشابهى در باره كلزا دادند. با توجه به اين كه در تحقيق حاضر از فرم سولفاتهٔ نيكل و تركيبات سولفاته ديكر در محلول غذايى هو گلند استفاده شد، بهجاست به به آثار

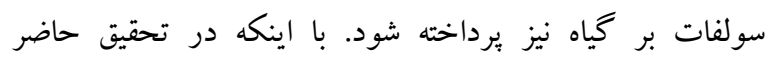

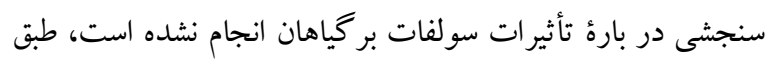

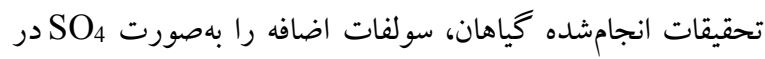

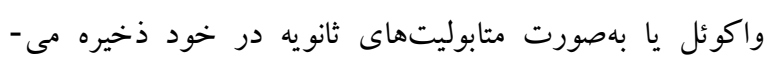

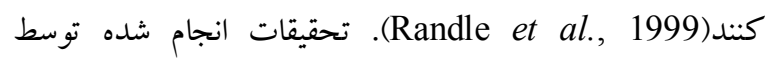
غاطن Kowalska غلظتهاى مختلف سولفات در محلول غذايى با نشانهاى

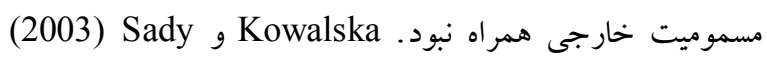




\section{REFERENCES}

Abbot, L.K. and Robson, A.D. 1977. Growth stimulation of subterranean clover with vesicular arb uscular mycorrhiza. - Aust. J. Agric. Res. 28: 639-649.

Alloway, B.J. 1995. In: Alloway B.J. (ed) Heavy metals in soils. - Blackie Academic and Professional, London, UK., pp 25-34.

Astros, M. and Bjorklund, A. 1996. Hydrogeochemistry of a stream draining sulfide bearing postglaci. - Water, Air, and Soil Pollut. 89:233-246.

Chaoui, A. and Ferjani, E. 2005. Effects of cadmium and copper on antioxidant capacities, lignification and and auxin degradiation in leaves of Pea (Pisium sativum L.) seedlings. - Comptes Rendus Biologies 328: 23-31.

Chen, C., Huang, D. and Liu, J. 2009. Functions and toxicity of nickel in plants: recent advantages and future prospects. - Clean 37:304-313.

Conway, L.P. and Bagyaraj, D. 1984. VA Mycorrhiza. CRC Press. 234-313 pp.

Dalurzo, H.C., Sandalio, L.M., Gomez, M. and Del Rio, L.A. 1997. Cadmium infiltration of detached pea leaves: effect on its activated oxygen metabolism. - Phyton. Ann. Rei. Botanica 37: 59-64.

Erdei, S., Hegedus, A. and Hauptmann, G. 2002. Heavy metal induced physiological changes in the antioxidative response system. - Acta Biologica Szegediensis 46: 8990.

Gajewska, E., Wielanek, M. and Sklodowska, M. 2009. Nickel induced depression of nitrogen assimilation in wheat root. - Acta Physiol. Plant 31:1291-1300.

Gionnopolitis, C.N. and Ries, S.K. 1997. Superoxide dismutase. I. Occurrence in higher plants. - Plant Physiol. 59: 309-314.

Guo, T.R., Zhang, G.P. and Zhang, Y.H. 2007. Physiological changes in barely plants under combined toxicity of aluminum, copper and cadmium. Colloids and Surface B. - Biointerfaces 57: 182-188.

Heath, R.L. and Packer, L. 1968. Photoproxidation in isolated chloroplasts.I-Kinetics and stoichiometry of fatty acid peroxidation. - Arch. Biochem. Biophys. 125: 189198.

Herschbach, C. and Ronnenberg, H. 1994. Influence of glutathione (GSH) on net uptake of sulphate and sulphate transport in tobacco plants. - J. Exp. Bot. 45: 1069-1076.

Hiraga, S., Sasaki, S., Ito, H., Ohashi, Y. and Matsui, H. 2001. A large family of class III plant peroxidases. - Plant and Cell Physio. 42: 462-468.

Hsu, Y.T. and Kao, C.H. 2004. Cd toxicity is reduced by nitric oxide in rice leaves. - Plant Growth Regul. 42: 227-238.

Kowalska, I. 2005. Effects of sulphate level in the nutrient solution on plant growth and sulphur content in tomato plants. - Folia Horticulturae Ann. 17: 91-100.

Kowalska, I. and Sady, W. 2003. Effects of different sulphate levels at the root zone on the concentration of mineral compounds in the leaves of greenhouse tomato grown on NFT. - Acta Hort. 604: 499-504.

Laspina, N.V. and Groppa, M.D. 2005. Nitric oxide protects sunflower leaves against Cd-induced oxidative stress. -Plant Science 169: 323-330.
Marchiol, L., Assolari, S. and Sacco, P. 2004. Phytoextraction of heavy metals by canola (Brassica na pus) and radish (Raphanus sativus) grown on multicontaminated soil. - Enviro. Pollut. 32: 21-24.

Mazhoudi, A., Chaui, M.H., Ghorbal, E. and Ferjani, E. 1997. Response of antioxidant enzyme to excess copper in tomato (Lycopersicon esculentum). - Plant Sci. 127: 129-137.

Michaelis, A., Takehisa, R. and Aurich, O. 1986. Ammonium chloride and zinc sulfate pretreatments reduce the yield of chromatid aberrations induced by TEM and maleic hydrazide in Vicia faba. - Mutal. Res. 173: 187-191.

Ochi, T., Ishigura, T. and Osakawa, M. 1983. Participation of active oxygen species in the induction of MDA single strand scissions by cadmium chloride in cultured Chinese hamster cells. - Mutat. Res. 122: 169-175.

Pitzchke, A., Fornazi, C. and Hirt, H. 2006. Reative oxygen species signaling in plants. - Antioxid. Redox Signal 8:1757-1764.

Quiroga, M. and Guerrero, M.A. 2000. A tomato peroxidase involed in the synthesis of lignin and suberin. - P1ant Physio. 122: 1119-1127.

Randle, W.M., Kopsell, D.E., Kopsell, D.A. and Snyder, R.L. 1999. Total sulfu and sulfate accumulation in onion is affected by sulfur fertility. - J. Plant Nutr. 22: 45-51.

Rao, K.V.M. and Sresty, T.V.S. 2000. Antioxidative parameters in the seedlings of pigeonpea Mill spauga in response to Zn and Ni stress. - Plant Sci.157: 113-128.

Salt, D.E., Kato, N., Kramer, U., Smith, R.D. and Raskin, I. 2000. The role of root exudates in nickel accumulation and tolerance in accumulator and non-accumulatore species of Thlaspi. - CRS Press LLC, London. pp 189-200.

Simon, T. and Eberhard, A. 2000. Effect of $\mathrm{Ni}$ and as on radish tuber cultivated on artificially pollut ed soils. - J. Soil Bio. 36: 73-80.

Sunderman, F.W. and Oskarsson, A. 1991. Metalsand their compounds in the environment. - In: Merian E, Weinheim VCH (eds).pp. 1101-1126.

Zwolsman, J.J.G. and Van Bokhoven, A.J. 2007. Impact of summer droughts on water quality of the Rh Inr River-a preview of climate change. - Water Sci. Technol. 56: 4555 .

$* * * * *$

Zolfagharlou, Ch. and Zare-Maivan, H. 2017. Interaction of vesicular arbuscular mycorrhiza with nickel heavy metal and its effect on the oxidative stress in barley. - Nova Biol. Rep. 3: 341-347.

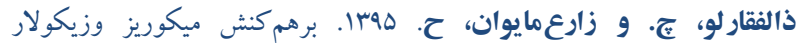

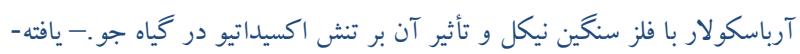

$$
\begin{aligned}
& \text { هاى نوين در علوم زيستى ب: MFV }
\end{aligned}
$$

